\title{
Distribution, protection and restoration of Taxus baccata L. in Ukraine
}

\author{
Oleh Hnatiuk ${ }^{1} \bowtie$, Vasyl Mohytych ${ }^{2}$, Matgorzata Sułkowska ${ }^{2}$ \\ ${ }^{1}$ National Forestry University of Ukraine, Educational and Research Institute of Forestry and Park Gardening, \\ Gen. Chuprynky 103, 79057 Lviv, Ukraine, e-mail: o.r.hnatiuk@gmail.com \\ ${ }^{2}$ Forest Research Institute, Department of Silviculture and Genetics of Forest Trees, Sękocin Stary, Braci Leśnej 3, \\ 05-090 Raszyn, Poland
}

\begin{abstract}
English yew is one of the most endangered species in Europe. Due to the specificity of this species, its natural regeneration is quite difficult. The aim of the study was to present the current situation of distribution, protection and restoration of the species in Ukraine. The study presents some characteristics of largest natural and artificial yew populations in the country and their protection. In situ and ex situ yew populations are quite different, in terms of bioclimatic conditions what does not affect to the growth characteristics of the populations. In addition, the activities related to the natural and artificial renaturalisation of the yew were analysed. Thus, tending of tree stands, where the natural regeneration of yew was inventoried can be recommended but it should be planned very individually regarding requirements of the site. The introduction of yew seedlings in the conditions of the managed forest is very difficult. Despite the complication of obtaining planting material and high cost, it is important measure to preserve the species. In Ukraine are successful examples of the seed transfer of yew populations by about $450 \mathrm{~km}$ in North-East direction (Carpathian yew population) and $700 \mathrm{~km}$ in North direction (Crimean yew population). It is an evidence of high ecological plasticity of the species. Moreover, some recommendations that could be useful for increasing the popularization of this species throughout the country were given in conclusions. The wider use of yew in public areas across the country due to unique value of species and more convenient protection of young seedlings. It is worth to continue the inventory of yew locations at the national level and study the possibilities to use as local sources to conservation of this species throughout the country.
\end{abstract}

\section{KEY WORDS}

English yew, in situ, ex situ, conservation measure, natural regeneration

\section{INTRODUCTION}

English yew (Taxus baccata L.) also known as European or Common yew, is a conifer tree species native to most of Europe, from southern Scandinavia to northern
Africa. It is a primarily dioecious tree species and monoecious individuals are rare, which causes problems as far exchange of genetic information between individuals in fragmented populations is concerned. Common yew is easily distinguished from other conifers by red 
berries. It is slow-growing but extremely long-living species, with some individuals up to 5000 years old (http://www.euforgen.org; Benham et al. 2016).

Although the distribution area is large, occurrence of the species is scattered and minimum temperatures regularly below $-20^{\circ} \mathrm{C}$ may be one of the limiting factors for its distribution (Zatloukal and Vančura 2004).
Common yew is found over the entire edaphic range, with the exception of highly acidic, poor and peat soils. Its occurrence is also limited on soils heavily affected by water.

The anthropogenic factor was a major reason which caused the decline of yew populations. In many European countries, yew is an endangered species, requir-

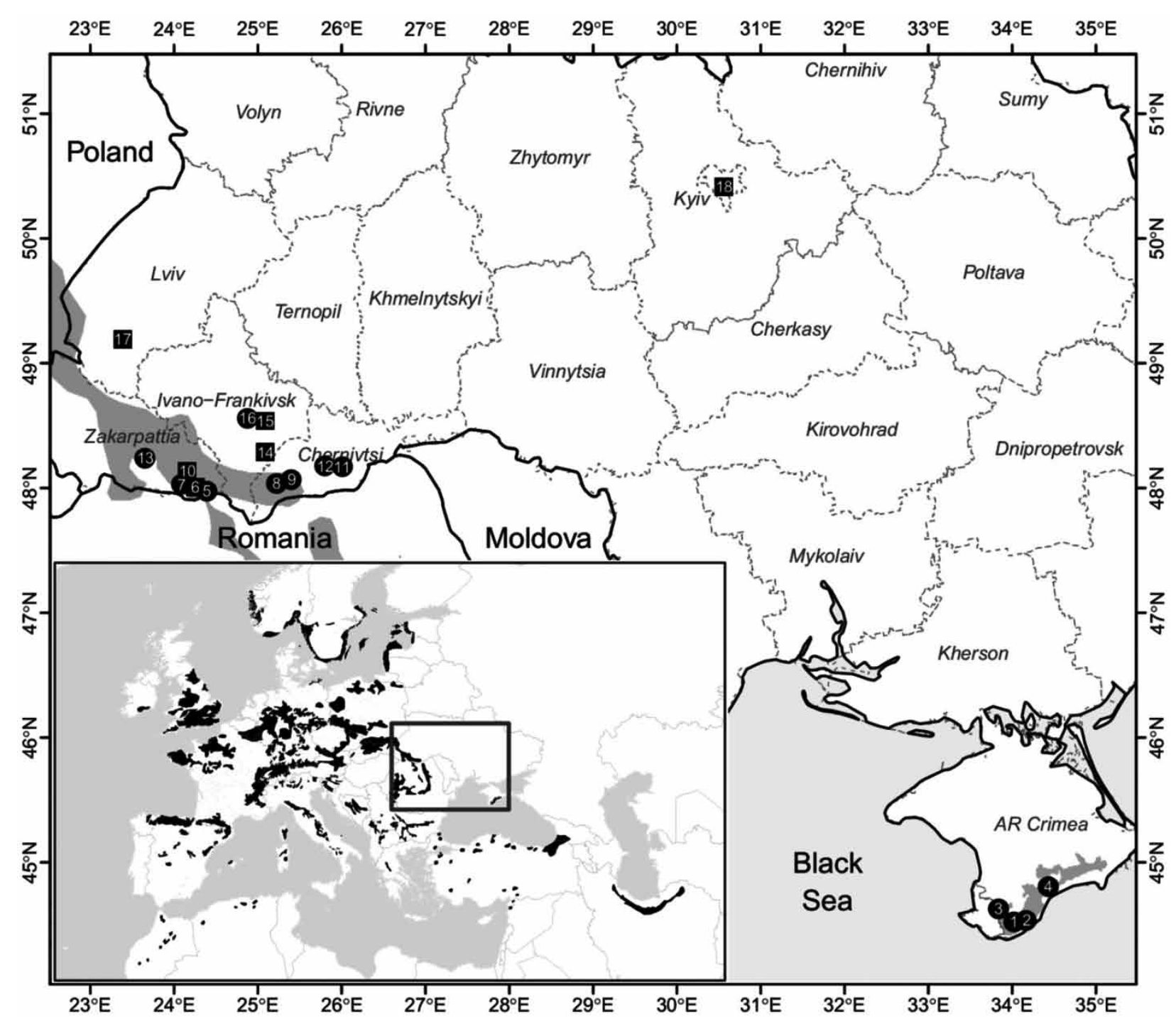

Figure 1. Location of Common yew sites in Ukraine (circles denote natural populations, square denote locations of artificially regenerated sites) and its distribution range (grey shape main map and black shape bottom left map) according to http://www. euforgen.org. Numbers on circles and squares denote locations: 1 - Grand Canyon of the Crimea, 2 - Uch-Kosh locality, 3 - Valley of the Belbek River, 4 - Tyrke Mountain, 5 - Marmarosh massif, 6 - Carpathian Biosphere Reserve, 7 - Kuziiskyi massif, 8 - Koshman locality, 9 - Velyki Markushi locality, 10 - Velykobychkivske Forest District, 11 - Tysovyi Yar locality, 12 - Vovchyi Yar locality, 13 - Uholsko-Shyrokoluzhanskyi massif, 14 - Hutsulshchyna National Nature Park 15 - Kolomyia Forest District, 16 - Kniazhdvir Natural Reserve, 17 - Skole Beskids National Nature Park, 18 - M.M. Gryshko National Botanical Garden 
ing both ex situ and in situ protection (Zatloukal and Vančura 2004).

The yew wood and other parts of the tree are poisonous. The species have a broad spectrum of anti-cancer activity compounds e.g. taxels (Lee 1998), which promoted the using of this species with pharmacological purposes.

The aim of the study was to present the current situation of distribution, protection and restoration of this species in Ukraine.

\section{THE DISTRIBUTION AND BIOECOLOGICAL PREFERENCES OF YEW IN UKRAINE}

In Ukraine, yew is distributed in the Carpathians and Crimean Mountains (Fig. 1). Yew occupies mainly brown eutrophic soils on carbonates. The species often growth in ravines, on rocks, steep slopes and it prefers the specific microclimate of high humidity and shade conditions.

In the Carpathian Mountains yew growth in isolated populations. The largest such population is located in the Kniazhdvir Nature Reserve in Ivano-Frankivsk administrative region (about 22,000 individuals; Boratyński et al. 2001). However, the species also rarely occurs in Zakarpattia - Carpathian Biosphere Reserve and Chernivtsi administrative regions - Tysovyi Yar Natural Monument (Didukh 2009, Pryazhko 2005). The species is distributed in beech and fir-beech forests (Cephalanthero-Fagion union, Querco-Fagetea class) at the altitude of 400 to $900 \mathrm{~m}$ a.s.l. The total area of forests with yew is about 285.0 ha. Generally, the yew grows as admixture species, understory of matured or overmatured forest stands and it forms small trees with DBH from 2 to $10 \mathrm{~cm}$ and height from 1.5 to $6.5 \mathrm{~m}$. Only some individuals possess DBH over $20 \mathrm{~cm}$ and height more than $10 \mathrm{~m}$ (Pavlyuk and Marchenco 2004; Zayachuk 2019). The Kniazhdvir Nature Reserve is characterised by: annual average temperature $8.4^{\circ} \mathrm{C}$ (Fig. 2A). The warmest month of the year is July, while the coldest month is January. Annual average temperature is $593 \mathrm{~mm}$. The driest month is February, while the greatest amount of precipitation occurs in July.

In the Crimean Mountains yew grows in the small populations or individually specimen from Karabi Yayla to Ai-Petri. The largest populations are located in the valley of the Belbek River (2,000 trees), near the Tyrke Mountain (800 trees), and the Grand Canyon of the Crimea (400 trees). The species occupies the sessile oak and beech forests (Dentario quinquefoliae-Fagion sylvaticae), particularly in the upper mountain elevations, at an altitude of 500-1200 m a.s.1. (Didukh 2009). The valley of the Belbek River is characterised by: an-
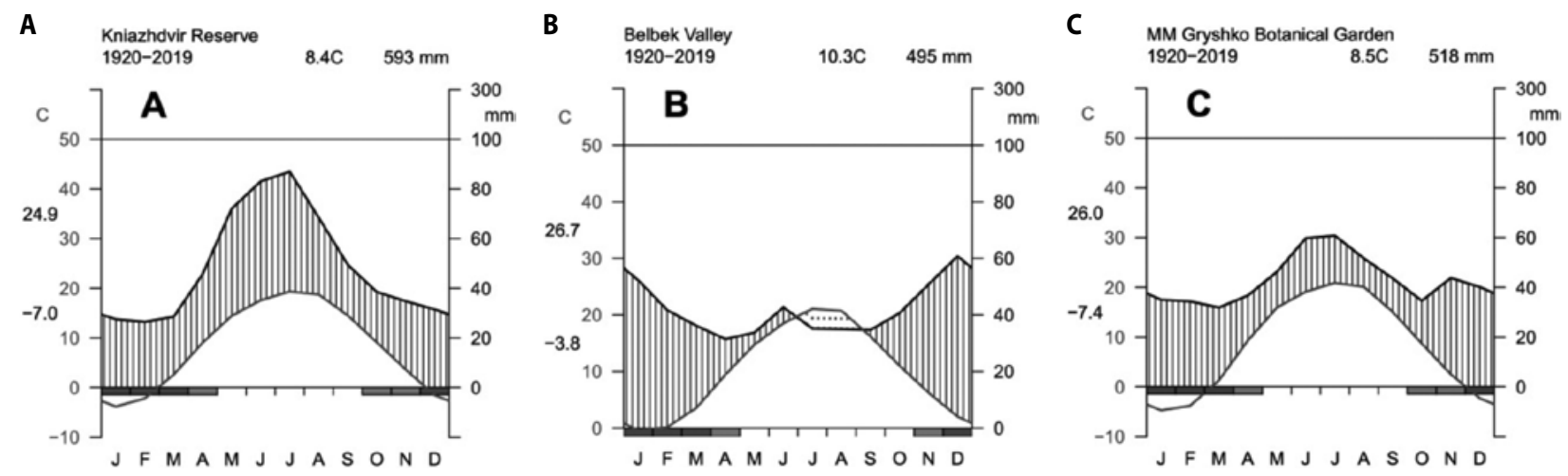

Figure 2. The Walter and Lieth climatic diagrams for Kniazhdvir Natural Reserve (A), Valley of Belbek river (B) and M.M. Gryshko National Botanical Garden (C). On the graphs monthly averages for precipitation (black line) and temperature (grey line). Annual averages of both elements in the upper part and at the left margin monthly averages annotations of the daily maximum and minimum temperatures of the warmest and coldest months. The rectangles under the $0^{\circ} \mathrm{C}$ axis show frost likelihood. Dark grey fill means that the average daily minimum is zero or negative, while light grey fill means that the absolute monthly minimum is zero or negative. The black vertical pattern depicts the humid months, while the dotted grey one shows when the aridity prevails (Guijarro 2014). The weather conditions of study sites for the period 1920-2019 were determined based on the data from Copernicus Climate Change Service [ECA\&D project (https://www.ecad.eu)] (Cornes et al. 2018) 
nual average temperature $10.3^{\circ} \mathrm{C}$ (Fig. 2B). The warmest month of the year is July, while the coldest month is January. Annual average precipitation is $495 \mathrm{~mm}$. The driest month is April, while the greatest amount of precipitation occurs in December.

In addition, yew was introduced to other Ukrainian regions outside natural distribution range. The species is utilised in garden and landscape designs in many cities across the country. As a result of different forms of European yew, it can be meet in recreational areas, parks and in public areas (Hnatiuk 2019). However, the most important ex situ units are botanical gardens, as an example of a successful transfer of yew to new growth condition is the M.M. Gryshko National Botanical Garden of the NAS of Ukraine in Kyiv (Shynder 2018). Where, the seed transfer was by about $450 \mathrm{~km}$ in North-East direction and $700 \mathrm{~km}$ in North direction for Carpathian and Crimean populations, respectively. In the condition of botanical garden, the annual average temperature is $8.5^{\circ} \mathrm{C}$ (Fig. 2C), the warmest month of the year is July, while the coldest month is January. Annual average precipitation is $518 \mathrm{~mm}$. The driest month is March, while the greatest amount of precipitation occurs in July.

\section{Process of decreasing the european yew POPULATIONS}

During the study of presence of pollen grains of Taxus baccata L. in the palynological materials of the RissWürm deposits, it was found that in the optimum of this interglacial, yew also took part in formation of the vegetation cover of current Ternopil administrative region Bezusko et al. (2013).

In ancient times, yew forests were widespread in the Carpathian and Precarpathian regions. There are many traces about it in toponymy (Kubijovyč 1980; Stoiko 1966). In Ukrainian, the name of yew sounds as 'Tys'. The numerous historical field names have such root word. Moreover, there are also villages and mountain rivers which names have such root word. For example, Tysovets village in Chernivtsi administrative region, Tysiv and Tysmenytsia villages in Ivano-Frankivsk administrative region, Chorna Tysa and Tysalovo villages, as well as Bila Tysa and Chorna Tysa rivers in Zakarpattia administrative region. The same situation is observed in neighbours countries (Dovčiak 2002; Dufková 2019;
Różycka 1989; Simon et al. 2018), where the species name sound similarly e.g.: 'Tisă' in Romania, 'Tis' in Slovakia and the Czech Republic, 'Cis' in Poland etc.

The studies of the disappearance of yew trees in the Ukrainian Carpathians are not too abundant. As a most advanced research can be considered: From the past of the yew (Kontny 1937). Still the 17th and 18th centuries yew was quite common in the Eastern Carpathians, while its valuable timber was the subject of intensive exploitation. However, when the study was carried out (30s of the 20th century) only decomposing trunks of cut yew trees had been reminded in the forest. One of such stump with the diameter $1.8 \mathrm{~m}$ was found near Verkhovyna in Ivano-Frankivsk administrative region. In first half of 19th century, the studies were pointed at the protection and inventory of yew in Ukrainian Carpathians (Sokołowski 1921; Szafer 1913). The description of the existing yew stands and protection the most significant of them (e.g. Kniazhdvir Natural Reserve) was an important contribution in process of decreasing of this species threatening. These data compared to later studies allow to identify trends that occur in some yew populations.

Currently, there are two main factors that the species occurrence decrease could influence. The natural one related to the slow growth of yew, which does not allow to compete with fast-growing tree species and anthropogenic factors related to all types of management in forests with the admixture of yew e.g. felling, harvesting bark or branches, grazing of cows, disturbing of soil cover.

\section{YEW PROTECTION IN THE COUNTRY}

The species is listed in the Red Book of Ukraine with the status of vulnerable. The awareness is crucial that if the negatively affected factors were more intensive then the vitality status of populations would be worse, then in the near future, the species may be classified as endangered. Moreover, the yew populations are also listed in the Green Book of Ukraine. It means that the violation of the status of site where the species grows e.g. the cutting of the trees and pruning is forbidden (Didukh 2009).

In Ukraine, few dozen individuals of yew with the age from 500 to 900 years old have been inventoried. Theirs DBH are more than $2 \mathrm{~m}$ and height as least $10 \mathrm{~m}$ 
(Shnayder et al. 2011). The oldest trees are located on the southern coast of Crimea, where in natural conditions 7 trees are registered. Their age is from 500 to 1300 years old with DBH more than $2.5 \mathrm{~m}$ (Bojko 2015). The oldest one is considered to be Zakharzhevskyi yew (Ai-Petri peak), whose age is about 1200-1300 years old with DBH $3.76 \mathrm{~m}$ and height $10 \mathrm{~m}$ (Hrynyk et al. 2010). However, among the Carpathian populations such old trees were not found. Here, the oldest and largest specimen grows near Dilove village (Zakarpattia administrative region). Its age is about $175-200$ years and height is $14.6 \mathrm{~m}$ (Polianchuk et al. 2020).

The Nature Reserve Fund of Ukraine also includes more than ten yew individuals, which grows outside natural distribution range of the species. Generally, it is group of trees in Botanical Gardens or alone Monument Trees. The age of the three oldest trees is estimated from 110 to 150 years old (Bojko 2015). Their height is from 6 to $10 \mathrm{~m}$. They are characterised by high vitality branches and lack of damage by pests or diseases. The trees produce seeds every year.

\section{Measures treatments in the Processes OF YeW RESTORATION AND CONSERVATION}

Due to the rarity of this species, the lack of research on a wide scale on the renaturalisation of this species are noted. Thus, there are many gaps in the process of selecting effective methods for its renewal, both natural and artificial one. For example, in the 80 s of last century, there was an opinion that beech trees of very large size interfere with the normal growth of yew. The ring barking had been performed to for individual beech trees to minimize their density to fulfill sufficiently favorable conditions for the growth of yew. However, the experiment was not satisfied, after increasing of the lightening yews were regenerated very poorly The gaps of withered beech trees turned out very good site for masse regeneration of undergrowth of fir and beech, while the growth rate of yew was slower one (Pavlyuk and Marchenco 2004). So, the taking into consideration the measure treatments which could influence light condition, it should be planned very carefully in the yew reserve. Yew has a natural competitive advantage in the struggle for survival with other tree species, because of its ability to withstand critical shading.
According to the studies conducted in Poland (Niemczyk et al. 2015), the proper growth and development of yew trees in a stand requires the creation of moderate light conditions (at the level of about 30\%). The height increments of yew seedlings were smaller one, at the sites with high density of canopy (openwork remains at the level of $20 \%$ or less). On such sites, the period of direct competition between yews and herbaceous plants is extended. Authors concluded that yew has greatest growth in oak and Scots pine forests, followed by spruce, fir and beech forests. The oak and Scots pine stands with yew participation are not common for Ukrainian Carpathians. However, especially oak forests can be similar to yew forests in the Crimean Mountains.

The preservation of yew populations is an important issue in other European countries. In the Czech Republic (Zatloukal and Vančura 2004), the yew practically disappeared from the forests and the species was declared to be a highly endangered. In the process of preservation of yew populations there were following directions for application measure treatments: theoretical (continuing research into the yew gene pool), administrative and legislative (increasing the effectiveness of legal protection in areas where yews occur; improving the method of management while controlling the number of browsing animals), implementation policy (support for natural regeneration and planting of yews where necessary using suitable reproductive material). Currently, in Ukraine the following actions are being taken to into account to renaturalize of yew: a) creation gene bank of planting material, b) sowing seeds and planting of seedlings in natural ecosystems, c) conducting phenological observations, d) establishment of reproduction areas; e) reconstruction of disturbed natural environments (Deyneka 2014; Kabal et al. 2014). Nowadays also, the inventory of other unknown forest areas with yew are conducted. Recently, 39 individuals were found in Zakarpattia administrative region. The trees are located at the area of 48.2 ha. The largest one is characterised by $31.7 \mathrm{~cm}$ of DBH and $12 \mathrm{~m}$ of height (Polianchuk et al. 2020).The main priorities for forest breeders are cultivation of quality planting material of yew from seed (Kolesnichenko et al. 2009; Lisoviy et al. 2016), as well as through vegetative propagation (Usoltseva 2009). Moreover, the research on the micropropagation of the species was also being conducted (Filo- 
nova 1999; Lisoviy 2015). In the future, all this conservation measures can allowed to increase the occurrence of yew using limited resources for reproduction.

\section{Natural Regeneration OF the SPECIES}

The Kniazhdvir Natural Reserve, due to the area and yew population size is the most useful object for the studies of yew natural regeneration in the country (Boratyński et al. 2001). Thus, in 1950s the natural regeneration of yew is less successful than in other species (Yuzkiv 1958). However, from 4 to 16 thousand of yew seedlings per 1 ha was observed here. The light is not an important factor for English yew seed germination (Dhar et al. 2013). The survival rate and growth increment of seedlings generally was better in higher light conditions (Iszkuło and Boratyński 2006). It could explain that in The Kniazhdvir Natural Reserve the most of seedlings (80-85\%) were 1-year old and mostly were found under the canopy of the mother tree (Yuzkiv 1958). However, in 1976 the percent of 1-year seedlings was slightly lover $76 \%$, while $2-3$ years old plants were participating in in $13 \%$ and older one as it follows: $4-7$ year $-8 \%, 8$ and older $-3 \%$ (Boratyński et al. 2001). One of the latest study that was established in 2001 (Iszkuło et al. 2005), showed that the number of yew seedlings was increased (more than 30,000 with height lover then $1.3 \mathrm{~m}$ ). In particular, the number of the youngest seedlings (height up to $0.05 \mathrm{~m}$ ) was less than in 1976 . The numbers of middleaged and oldest seedlings/saplings (height $0.05-1.3 \mathrm{~m}$ ) were a few times higher in 2001. It was important that there was no threat to seedling caused by grazing. The game animals are an extremely serious threat to the natural regeneration of yew (Zatloukal and Vančura 2004). So, we can conclude that natural regeneration for Kniazhdvir Natural Reserve is satisfactory and increase during the last 50 years of 20th century.

\section{ArtifiCial regeneration OF the SPECIES}

One of the ways to solve this problem is to create an artificial forest stands with the participation of yew, especially in places of its former existence (Herbut and Turis 2008). The in-situ and ex-situ methods of yew conservation are conducted in the artificially managed forest stands in the Ukrainian Carpathians. According to Pavlyuk and Marchenco (2004), during the period from 1969 to 2001, the Pechenizhyn forestry (Kolomyia Forest Districts) were planted 35.4 ha of artificial forests with the yew participation. Unfortunately, we identify only 23.0 ha of artificial forest from which the yew is preserved only within the 18.9 ha (Hnatiuk and Huz 2018).

In the Ukrainian Carpathians, according to our studies, the total area of artificial forest stands with the admixture of yew, is 24.15 ha (Tab. 1). While, the problems and possibilities of the renaturalization of the species are constantly analysed (Polianchuk et al. 2020). The recommendations for the cultivation and the creation of biologically stable forest stands with yew in composition were elaborated, based on the gained experience (Herbut and Turis 2008). The economic value of establishing of stands was not neglected. Despite the complication and high cost of obtaining planting material, the preservation of yew seedlings complicated in the conditions of the managed forests.

Table 1. Artificially regenerated sites in Ukrainian Carpathians

\begin{tabular}{|l|c|c|}
\hline \multicolumn{1}{|c|}{ Unit } & $\begin{array}{c}\text { Established } \\
\text { in }\end{array}$ & $\begin{array}{c}\text { Total } \\
\text { area, ha }\end{array}$ \\
\hline Carpathian Biosphere Reserve & 2013 & 0.75 \\
\hline Hutsulshchyna National Nature Park & $2003-2013$ & 0.10 \\
\hline Kolomyia Forest District & $1973-1984$ & 18.90 \\
\hline Skole Beskids National Nature Park & $2008-2014$ & 3.10 \\
\hline Velykobychkivske Forest District & 2010 & 1.40 \\
\hline Total & & 24.15 \\
\hline
\end{tabular}

\section{Conclusions:}

- In Ukraine, the in situ and ex situ yew populations are quite different, in terms of bioclimatic conditions what does not affect to the growth characteristics of the populations.

- Tending of tree stands, where the natural regeneration of yew was inventoried can be recommended but it should be planned very individually regarding requirements of the site.

- Despite the complication and high cost of obtaining planting material, the introduction of yew seedlings 
in the conditions of the managed forest is very difficult.

- In Ukraine are successful examples of the seed transfer of yew populations by about $450 \mathrm{~km}$ in North-East direction (Carpathian yew population) and $700 \mathrm{~km}$ in North direction (Crimean yew population). It is an evidence of high ecological plasticity of the species.

- It is recommended wider use of yew in public areas across the country due to unique value of species and more convenient protection of young seedlings.

- It is important to continue the inventory of yew locations at the national level and study the possibilities to use as local sources to wider conservation of this species throughout the country.

\section{ACKNOWLedgments}

We acknowledge the E-OBS dataset from the EU-FP6 project UERRA (http://www.uerra.eu) and the Copernicus Climate Change Service, and the data providers in the ECA\&D project (https://www.ecad.eu). The authors also would like to thank Marcin Klisz (Forest Research Institute) for his support to obtain presented climate data for this study.

\section{References}

Benham, S.E., Houston Durrant, T., Caudullo, G., de Rigo, D. 2016. Taxus baccata in Europe: distribution, habitat, usage and threats. In: European Atlas of Forest Tree Species (eds.: J. San-Miguel-Ayanz, D. de Rigo, G. Caudullo, T. Houston Durrant, A. Mauri). Publ. Off. EU, Luxembourg.

Bezusko, L.G., Karpiuk, T.S., Mosyakin, S.L., Bezusko, A.G. 2013. Paleochorological characteristics of Taxus baccata L. distribution during the optimal phases of the Riss-Wurm in terglacial in the plain part of Ukraine (in Ukrainian). Ukrainian Botanical Journal, 70, 35-41.

Bojko, N.S. 2015. The yew tree (Taxus L.) as an item of historical and cultural heritage in the World and Ukraine (in Ukrainian). Forestry and Decorative Gardening, 229, 216-223.
Boratyński, A., Didukh, Y., Lucak, M. 2001. The yew (Taxus baccata L.) population in Knyazhdvir: Nature Reserve in the carpathians (Ukraine). Dendrobiology, 46, 3-8.

Cornes, R.C., van der Schrier, G., van den Besselaar, E.J.M., Jones, P.D. 2018. An ensemble version of the E-OBS temperature and precipitation data sets. Journal of Geophysical Research: Atmospheres, 123, 9391-9409.

Deyneka, M. 2014. Ways of improvement of economic and nature protection activity of national natural park „Skolyvsky Beskydy” (in Ukrainian). Efektyvna Ekonomika, 3.

Dhar, A., Vacik, H., Ruprecht, H., Al., E. 2013. Population dynamics of endangered English yew (Taxus baccata L.): implication for conservation and management. In: Endangered Species: Habitat, Protection and Ecological Significance. Nova Science Publishers.

Didukh, Y.P. 2009. Red data book of Ukraine. Vegetable kingdom (in Ukrainian). Hlobalkonsaltynh, Kyiv, Ukraine.

Dovčiak, M. 2002. Population dynamics of the endangered English yew (Taxus baccata L.) and its management implications for biosphere reserves of the Western Carpathians. Final report on Young Scientist Award.

Dufková, K. 2019. Dendronyma v sídelních jménech českých zemí (in Czech).

Filonova, L. 1999. Introduction in vitro culture of Taxus baccata L. and obtaining of taxol produced callus lines (in Ukrainian). Institute of Cell Biology and Genetic Engineering, National Academy of Science of Ukraine.

Guijarro, J.A. 2014. User's guide to Climatol.

Herbut, F.F., Turis, E.V. 2008. To the question of the renaturation yew (Taxus baccata) in Carpathian (in Ukrainian). Scientific Bulletin of Uzhhorod University, Series Biology, 22, 63-66.

Hnatiuk, O. 2019. Using yew (Taxus baccata L.) in park gardering (in Ukrainian). In: International Scientific and Practical Conference "The Current State and Prospects for the Development of Landscape Architecture, Garden Design, Urban Ecology and Phytomelioration” (ed.: R.B. Dudyn et al.), Lviv, April 4-5, 2019. Liha-pres, Lviv, 96-98. 
Hnatiuk, O.R., Huz, M.M. 2018. The common yew (Taxus baccata $\mathrm{L}$.) in the artificial forests of the Ukrainian Carpathians (in Russian). In: Horticultură, Viticultură Şi Vinificaţie, Silvicultură Şi Grădini Publice, Protecţia Plantelor ( ed.: L.Volconovici). UASM, Chișinău, Moldova, 449-455.

Hrynyk, P.I., Stetsenko, M.P., Shnaider, S.L., Lystopad, O.H., Boreiko, V.Ye. 2010. Ancient trees of Ukraine. PROON Ukraina, Kyiv, Ukraine.

Iszkuło, G., Boratyński, A. 2006. Analysis of the relationship between photosynthetic photon flux density and natural Taxus baccata seedlings occurrence. Acta Oecologica, 29, 78-84.

Iszkuło, G., Boratyński, A., Didukh, Y., Romaschenko, K., Pryazhko, N. 2005. Changes of population structure of Taxus baccata L. during 25 years in protected area (Carpathians, western Ukraine). Polish Journal of Ecology, 53, 13-23.

Kabal, M.V., Hleb, R.K., Polianchuk, I.Y., Sukhariuk, D.D. 2014. Forest groups with the participation of yew in the Carpathian Biosphere Reserve (in Ukrainian). In: Conservation and Reproduction of Biodiversity of Nature Reserves. ZUKTs, Lviv, Ukraine, 82-87.

Kolesnichenko, O.V., Sliusar, S.I., Yakobchuk, O.M., Halkina, N.S. 2009. Peculiarities of seed production and results of introductory test of Taxus baccata L. in the botanical garden of NAU (in Ukrainian). Ukrainian Journal of Forest and Wood Science, 135, 48-54.

Kontny, P. 1937. Z przeszłości cisa (Taxus baccata L.) (in Polish). Sylwan, 55, 29-68.

Kubijovyč, V. 1980. Encyclopedia of Ukraine (in Ukrainian). Volume II/9. Logos GmbH, Munich.

Lee, M. 1998. The yew tree (Taxus baccata) in mythology and medicine. Proceedings of the Royal College of Physicians of Edinburgh, 28, 569-575.

Lisoviy, M.M. 2015. features of sterilization and introduction to the culture in vitro of explants of Taxus baccata L. (in Ukrainian). Scientific Bulletin of UNFU, 25, 8-13.

Lisoviy, M.M., Guz, M.M., Hnatiuk, O.R. 2016. Peculiarities of seed and vegetative propagation of berry yew (in Urainian). Scientific Bulletin of UNFU, 26, 99-110.

Niemczyk, M., Żółciak, A., Wrzesiński P. 2015. The influence of stand canopy openness on the growth of common yew (Taxus baccata L.) (in Polish with English summsry). Leśne Prace Badawcze, 76, 42-48.

Pavlyuk, V.V., Marchenco, O.M. 2004. Yew (Taxus baccata) - valuable relict of the tertiary period. Scientific Bulletin of UNFU, 16, 35-40.

Polianchuk, I.Y., Hleb, R.Y., Sukhariuk, D.D., Kozurak, A.V. 2020. Natural and artificial tree stands with Taxus baccata L. in the Marmarosh massif (in Ukainian). Monitoring and protection of biodiversity in Ukraine. Flora and mushrooms. Part 1, 16, 170-173.

Pryazhko, N. 2005. Sex structure of Taxus baccata population in Ukrainian Carpathians (in Ukrainian). Newsletter of Precarpathian University named after V. Stefanyk - Biology, 5, 5-8.

Różycka, I. 1989. Nazwy 'buk' (Fagus silvatica), 'cis' (Taxus baccata), ‘jawor’ (Acer pseudoplatanus), 'modrzew' (Larix polonica) i pochodne w makrotoponimii polskiej (in Polish). Acta Universitatis Lodziensis. Folia Linguistica, 20, 53-94.

Shnayder, S., Boreyko, V., Stetsenko, N. 2011. 500 exceptional trees of Ukraine (in Russian). Lohos, Kyiv, Ukraine.

Shynder, O.I. 2018. Populations of rare species of spontaneous flora in the M. M. Gryshko National Botanical Garden NAS of Ukraine (Kyiv) (in Russian). Journal of the Belarusian State University. Biology, 3, 62-71.

Simon, A., Arsene, G., Vechiu, E., Enescu, C.M. 2018. Forest trees in Romanian toponymy. Current Trends in Natural Sciences, 7, 151-156.

Sokołowski, S. 1921. Cis na ziemiach polskich i w krajach przyległych (in Polish). Ochrona Przyrody, 2, 4-22.

Stoiko, S.M. 1966. The Knyazhdvir yew Grove (in Russian). In: Carpathian Reserves (ed.: V.Y. Komendar). Karpaty, Uzhorod, Ukraine.

Szafer, W. 1913. Cisy w Kniaźdworze pod Kołomyją jako ochrony godny zabytek przyrody leśnej (in Polish). Sylwan, 31, 447-452.

Usoltseva, O.H. 2009. Peculiarities of vegetative propagation of yew by stem cuttings in the steppe of Ukraine (in Ukrainian). Collection of Scientific Papers of Uman National Agricultural University, 71, 183-187. 
Yuzkiv, M. 1958. Yew in Knyazhdvir forest in the Prykarpattia (in Ukrainian). Materials on nature protection in Ukraine, 1, 27-41.

Zatloukal, V., Vančura, K. 2004. Common yew (Taxus baccata L.) and its genetic diversity in the Czech Republic. In: Conifers Network, Report of the Second (20-22 September 2001, Valsaín, Spain) and Third (17-19 October 2002, Kostrzyca, Poland)
Meetings (eds.: K. Vančura, B. Fady, J. Koskela, C. Mátyás). International Plant Genetic Resources Institute, Rome, Italy, 25-30.

Zayachuk, V. 2019. Taxus baccata L. in the Ukrainian Carpathians: distribution, participation in the forest stands and productivity (in Ukainian). Proceedings of the Forestry Academy of Sciences of Ukraine, 18, 57-67. 